\title{
A framework for comparing collaborative management of Australian and New Zealand water resources
}

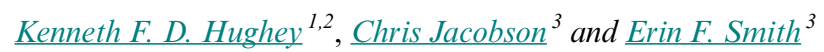

\begin{abstract}
Collaborative management of natural resources involves two or more parties working together to govern and/or manage a set of resources within a defined area. Although a number of collaborative management frameworks have been developed for protected area and fisheries management, few exist for freshwater resources that enable their comparative analysis. We present a framework of collaborative management for freshwater resources comprising three elements: scope, governance, and management. Application of the framework to 11 cases from Australia and New Zealand differentiates between primarily consultation/government-based arrangements through to cogovernance arrangements. Our framework differs from others because it highlights the multiscalar and nested nature of collaborative management arrangements that influence effective water resource management. Our analysis highlights the diversity of arrangements that exist for freshwater resource management. Cases involving indigenous groups, a social tradition of waterways management, and those outside the scope of national water resource management reforms generally had higher levels of power sharing and involvement. We argue for greater attention to the effectiveness of and links between governance and management processes to ensure collaborative management remains innovative and appropriate to context. We contribute a framework that contains a continua and three core elements that enables a parsimonious evaluation that could be applied to other resource management contexts and, thus avoids criticism of overly prescriptive, simplistic, and idealistic analysis.
\end{abstract}

Key Words: Australia; cogovernance; collaborative management; governance; management; New Zealand; scope; water resources

\section{INTRODUCTION}

It is increasingly recognized that successful environmental management requires a holistic perspective that engages community, industry, and government. In response, many forms of cooperative-, collaborative-, joint-, and comanagement and governance have emerged. For the purposes of this article, we define collaborative management as "a partnership by which two or more relevant social actors collectively negotiate, agree upon, guarantee and implement a fair share of management functions, benefits and responsibilities for a particular territory, area or set of natural resources" (Borrini-Feyerabend et al. 2004:69). Collaborative management is not a new approach, having been applied in fisheries, forestry, and protected area management for around a century (Agrawal 1995, Jentoft and McCay 1995, Borrini-Feyerabend et al. 2004). Despite also being commonly applied in freshwater management, comparative analyses are largely absent from the academic literature (but see Eberhard et al. 2017).

The purpose of this article is to contrast contemporary and innovative collaborative arrangements. We do so through the development of a framework that compares scope, governance, and management along a power-sharing continuum. This framework provides a rapid method for identifying and sharing lessons on the collaborative management of natural resources. We illustrate its application using freshwater management cases from two different countries: a federation of self-governing states in Australia, and, in the case of New Zealand, a Westminster-style government with national, regional, and local tiers. Both governments recognize the rights of indigenous peoples, in Australia through native title and in New Zealand through the Treaty of Waitangi settlement process (Jacobson et al. 2014).
Through framework application, we demonstrate enhanced understanding about the drivers that shape the nature of collaborative management arrangements and provide critical insights that will inform future freshwater management internationally.

Collaboration in governance and management of natural resources has occurred since the 1890s (Jentoft and McCay 1995), and incorporates a suite of terms such as comanagement, cooperative management, and cogovernance of natural resources. Comanagement refers to formalized power sharing arrangements (Armitage et al. 2007); in some contexts, e.g., Australia, comanagement refers principally to relationships between indigenous peoples and the nation state, as per protected area management. In instances where formalized arrangements, either statutory or voluntary, do not exist, are limited in scope, or are unequal between collaborating parties, the term cooperative or collaborative management is used. More recently, the term cogovernance has been used, although this generally refers to formal agreements for sharing of decision-making powers, but not necessarily responsibility for implementing, regulating, or enforcing actions agreed to. Cogovernance provides an attempt to increase deliberation and participation in decision making, and may or may not increase legitimacy of disenfranchized rights, depending on who is engaged in the arrangement (Brinbaum 2016). Thus, we use the term "collaborative management" in reference to a full suite of arrangements, of which comanagement and cogovernance are two. Our use is categorical rather than hierarchical, given that there is no singular definition of each term, and that the appropriateness of any term or set of arrangements is subjective in judgement (see Takeda and Røpke 2010).

${ }^{1}$ Department of Environmental Management, Lincoln University, Christchurch, New Zealand, ${ }^{2}$ Sustainability Research Centre, University of the Sunshine Coast, Queensland, Australia, ${ }^{3}$ Sustainability Research Centre, University of the Sunshine Coast, Queensland, Australia 


\section{COLLABORATIVE MANAGEMENT APPROACHES}

Approaches to collaborative management are diverse because of its emergence from the management of multiple natural resources types, and from multiple socio-political contexts. Community and state can interact in collaborative management in partnership, in joint organizations, or in nested systems (Carlsson and Berkes 2005). Detailed descriptive models have been developed. For example, Plummer and Fitzgibbon (2004) incorporate 18 elements into their framework, linked to context (three rights sets), components (preconditions, characteristics, and outcomes), and linking methods, with multiple feedbacks. Simpler continua, frameworks, and typologies of collaborative management have also been developed that support lesson sharing and improvement of practice. Borrini-Feyerabend (1996), for instance, described collaborative management as a range of approaches along a continuum from full agency control to full stakeholder control, with the latter involving increased contribution, commitment, and accountability of stakeholders facilitated by fully devolved management. Sen and Nielsen (1996) identify a similar continuum of practice for collaborative management of fisheries that varies on the basis of power sharing; it can be instructive or consultative (i.e., communities are consulted and inform government decisions), advisory (where a group has specific input into management decisions but no power), cooperative (where communities and government are partners in decision making), or informative (where responsibilities are delegated to communities).

In the Australian context, Smyth (2001) and Szabo and Smyth (2003) depict three different models of collaborative protected area management. These vary in relation to ownership, management planning, the voluntary/optional nature of arrangements, with whom land management authority resides, costs and security of arrangements. Alternatively, Hill et al. (2012) classify collaborative management between indigenous peoples and government as a position in a three dimensional space generated by consideration of power-sharing, intercultural purpose, and inclusiveness of participation. The common elements in these approaches to conceptualizing comanagement include power sharing, governance (rule setting), management (implementation), and relational context (context). The latter is important, given the criticisms of idealized depictions of comanagement that fail to account for changes in interrelationships between actors over time, the lack of critical reflection on whether power sharing is consensual, and parallel arrangements (Fischer et al. 2014).

Although typologies exist for the collaborative management of fisheries, wildlife, and protected areas management, few similar analytical frameworks exist for freshwater management. Margerum and Robinson (2015), building from Margerum (2008), classify arrangements as action, organization, or policy level, and either as cooperative or coordinated. However, the full range of collaborative approaches evident in other typologies are not covered by Margerum and Robinson's framework, nor are emerging multiscalar collaborative approaches that can include policy, organization, and action based responses, e.g., collaborative management of Te Waihora in New Zealand (Memon and Kirk 2012).

Collaborative management, however, has emerged as an important means of managing both water quality and quantity.
Analyses tend to emphasize whether the resource is managed effectively in accordance with principles for common property resources (Ostrom 1990). Although analysis in relation to common pool resource management principles can be used to assess the effectiveness of arrangements, it does not provide for nuanced analysis of similarities and differences, nor does it aid in generating new understanding about the divergent contextual drivers specifically within water management contexts; framework type analyses may be more useful in this regard.

\section{JURISDICTIONAL CONTEXT}

Comparing collaborative management across countries requires an understanding of the jurisdictional context. Ongoing drought in Australia has hastened reforms targeted at greater coordination of water management regimes across jurisdictions. At the state level, these reforms have typically required a statutory response, e.g., the 1989 Water Act (State Government of Victoria 1989) or the 2000 Water Act (State Government of Queensland 2000) and reinforced top-down water planning in which stakeholder input is largely limited to an advisory role. The Australian water management landscape has been shaped by several macro drivers including (1) the Australian Constitution; (2) commitment to market-based mechanisms; (3) severe drought conditions; and (4) regional approaches to natural resource management. Section 100 of the Australian Constitution specifies that responsibility for water management resides with the state and territory governments. When viewed in historical context, water policies and management mechanisms have differed markedly between Australian jurisdictions as state and territory governments pursued their individual priorities (Pigram 2006). Notwithstanding contemporary reforms that have been targeted toward increased coordination between Australian jurisdictions, these legacies continue to shape water management arrangements. Australian water management is also characterized by a commitment to statutory-based water planning and complex market-based arrangements (see the 1994 Council of Australian Governments' water reform framework and the Intergovernmental Agreement on a National Water Initiative 2004).

The context is different for New Zealand where the Resource Management Act 1991 (Government of New Zealand 1991) sets the framework for an integrated approach to planning for sustainable resource management, and appearing to seamlessly link national, regional, and local government planning. It also "enshrined" indigenous interests in planning and environmental management, following significant claims around water and coastal fisheries degradation brought by indigenous Māori tribes under the Treaty of Waitangi (Jacobson et al. 2016a). The relationship enshrined in the RMA was an early signal of collaborative arrangements to come in New Zealand's freshwater management, and of the role Māori were to play in these. This signal has been further driven by the National Policy Statement for Freshwater Management (Ministry for the Environment 2014) which included specific mention of Te Mana o te Wai, the status and importance of water to Māori.

\section{METHODS}

There are numerous examples of collaborative water resource management in Australia and New Zealand. To effectively illustrate the use of our analytic framework we selected a range of management examples based on process, design, and geography. The following criteria were used to select cases: 
- The collaborative group has an instrumental function, e.g. developing a management plan, with membership reaching beyond government;

- A diversity of current and innovative (collaborative management) arrangements within each country are represented;

- Examples from each country where multiple collaborative arrangements exist within the same catchment;

- Sufficient information was available to enable analysis; and

- Geographic diversity is represented, i.e., across Australian states/territories and including the North and South Islands of New Zealand.

Using these criteria, 11 collaborative freshwater management arrangements were chosen and subjected to document analysis (Fig. 1, Tables 1 and 2). Seven cases were from Australia and four from New Zealand and were believed sufficient to develop and test a framework to inform future development of freshwater collaborative management arrangements and provide insight to deliver on the aims of this paper.

Fig. 1. Location of the 11 collaborative groups.

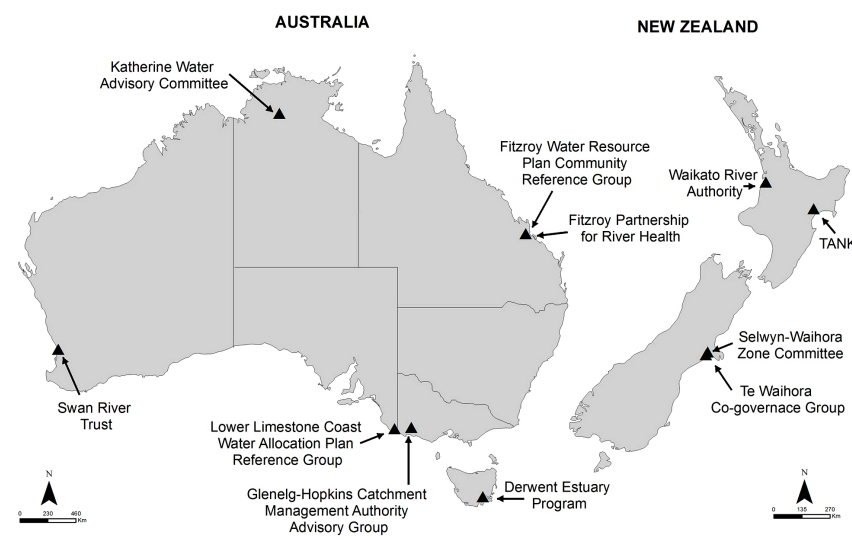

Our Australian cases exclude (1) examples of community owned water infrastructure, e.g., irrigation schemes; (2) examples from New South Wales where freshwater management occurs at the catchment scale, but community involvement is largely limited to public consultation and does not allow for nongovernment stakeholders to participate in an advisory role; and (3) the Murray-Darling Basin, given that it is a unique arrangement involving the Australian state/territory governments referring their constitutional water management powers to the Australian Commonwealth Government. The latter in particular is an unusual set of arrangements that can only be applied given (i) this is both an environmental matter of national importance, (ii) because the catchment crosses state boundaries and therefore a case could be made beyond the powers subscribed to individual states under federation, and (iii) because there is no comparison in New Zealand.

Almost any natural resource management body could arguably fit these criteria but we have chosen one case study per state given contextual differences in the way each addresses freshwater management. Based on the exploratory nature of our framework, not all possible cases from across Australia have been included, which is a limitation of the research. Our New Zealand cases exclude regional government planning processes, and two additional major cases: the Guardians of Manapouri, with its focus on water quantity rather than water quality, and the Motueka Integrated Catchment Management process, because of limited scope of analysis and our interest in a diversity of arrangements. We have also excluded the Ngāi Tahu Crown Settlement Act 1998 mandated Joint Management Plan arrangement between Ngāi Tahu and the Department of Conservation for public conservation lands on the lake margin of Te Waihora, given that the current cogovernance arrangements are much broader in physical scope. Thus, the framework we developed could similarly be applied to sharing lessons from programs where state government or equivalent is working with traditional owners under statutory mandates to implement collaborative freshwater management.

\section{Data collection}

A two-phase desktop review of water management arrangements was conducted for each case. First, case-specific and other relevant web sites were searched for information applicable to each case, as well as information pertaining to legislation and policy arrangements at national, state/territory (Australia), and regional (New Zealand) scales. All information was recorded in a spreadsheet against the categories outlined in the data analysis section to facilitate cross-case comparisons. Second, a search of the academic literature was conducted using three databases: Scopus, Web of Science, and Google Scholar, for any other analyses related to these cases. The first 100 hits retrieved from the Google Scholar searches were inspected for broad relevance to the project. After scanning all relevant documents from both phases, we created a master file of core references for each case (Appendix 1).

\section{Data analysis}

We created a framework matrix to support case analysis. The yaxis represents a continuum of power sharing, based on BorriniFeyerabend et al. (2004) and Sen and Nielsen (1996), moving from consultation/government-based (top of the continuum) to cogovernance (bottom of the continuum), and an x-axis covering scope, governance, and management. The terms used in this matrix are those typically used in both Australia and New Zealand. We positioned cases along this continuum, based on assessments of their characteristics. Although power sharing provided a useful means to classify cases, relative positioning also required us to consider the scope of participation across the breadth of management activities and the statutory nature of the group. The elements on the $\mathrm{x}$-axis encompass the range of responsibilities and actions, and characteristics and behaviors, encompassed within all known approaches to collaborative water management being undertaken in Australasia (see Jacobson et al. 2014).

\section{Scope}

Arrangements vary in purpose, time frame, and the extent to which they address either water quality or water quantity issues (or both). Arrangements also differ in terms of governance, with processes operating at national, state, regional, and local scales. Specifically there are three subelements: purpose, time frame, and 
Table 1. Descriptive context of the Australian collaborative groups.

\begin{tabular}{ll}
\hline Purpose & Physical scope \\
\hline $\begin{array}{l}\text { Derwent Estuary Program, Tasmania (DEP) } \\
\text { Develop and implement an } \\
\text { environmental strategy for the estuary }\end{array}$ & $\begin{array}{l}\text { The Derwent Estuary between New Norfolk (upstream) Derwent Estuary Partnership Agreement } \\
\text { and a line between Tinderbox and the Iron Pot } \\
\text { (downstream). } \\
\text { Note: Although the estuary is a brackish water body, it } \\
\text { includes a significant freshwater component. }\end{array}$
\end{tabular}

Fitzroy Partnership for River Health, Queensland (FPRH)

To monitor and evaluate the health of The Fitzroy Basin. Includes shallow groundwater, rivers, the river basin off-stream wetlands, and estuaries in the Fitzroy Basin and near-shore coastal and marine environments.

Fitzroy Partnership for River Health Memorandum of Understanding; Fitzroy Partnership for River Health Operating Rules

Fitzroy Basin Community Reference Panel, Queensland (FB)

Make recommendations for inclusion The Fitzroy Basin. Surface water and some groundwater in 10-year plan management areas.

Water Act 2000 (State Government of Queensland 2000)

Glenelg-Hopkins Catchment Management Authority Advisory Group, Victoria (GH) Make recommendations for inclusion The Glenelg Hopkins region covers approximately in 8-year strategy $\quad 26,910 \mathrm{~km}^{2}$ from Ballarat in the east to the border of South Australia in the west. And stretching from the southern coast of Victoria to the townships of Harrow and Ararat in the north.

Katherine Water Advisory Committee, Northern Territory (KWAC) Make recommendations for inclusion The Plan applies to water contained within the in 10-year plan; different committee unconfined and confined Tindall Limestone Aquifer reviews plan within the Katherine River Catchment. It does not directly apply to the management of surface water extractions.

Water Act 1989 (State Government of Victoria 1989)

Water Act (Government of Northern Territory 1992)

Lower Limestone Coast Water Allocation Plan Reference Group, South Australia (LLC) Water Allocation Plan for the Lower Two distinct underground water systems spanning Limestone Coast Prescribed Wells $1,450,000$ hectares in southeast South Australia. Area 2013 Extending from the coast east to the Victorian border and north to Padthaway.

Natural Resource Management Act 2004 (State Government of South Australia 2004)

Swan River Trust, Western Australia (SRT)

To manage the health of the Swan Canning River through plan development and reporting

The Swan and Canning rivers flow through the Perth Swan and Canning Rivers Management including the Swan Canning Riverpark, which is 72.1 Australia 2006) $\mathrm{km}^{2}$ of public land and adjoining river reserve.

water values. We attempted to weight the relative emphasis on particular water values, e.g., ecosystem health, recreation, or cultural, to indicate the broader role of freshwater in the delivery of ecosystem benefits and values the groups believed were most important to manage for. We used a three-category scoring system, from one star (low level of emphasis) to three stars (high level of emphasis).

\section{Governance}

Collaborative management, as we define it, involves the establishment of a new body or group(s), sometimes with decision-making authority. These groups vary in relation to eight subelements:

- Group membership, representation, and decision-making processes;

- Establishment of subgroups, resulting in nested arrangements;

- Inclusion of indigenous representatives;
- Statutory nature;

- Group mandate;

- Resourcing;

- Ability to adapt governance arrangements; and

- Transparency of governance

\section{Management}

Although the focus of collaborative management can be on either or both of governance and management, the inclusion of monitoring and evaluation of both process (e.g., Izurieta et al. 2011) and actions (Hockings et al. 2004) facilitates transparent governance and management and recognizes that both are learning processes (Berkes 2009). We assessed the existence of each in case studies as evidenced through reporting. Thus there are two subelements: monitoring and reporting. 
Table 2. Descriptive context of the New Zealand collaborative groups.

\begin{tabular}{ll}
\hline \hline Purpose & Physical scope \\
\hline $\begin{array}{l}\text { Selwyn Waihora Zone Committee (SWZC) } \\
\text { Consultation, assessment, and }\end{array}$ & $\begin{array}{l}\text { Selwyn, Waikirikiri, Waimakariri, Rakaia, Wilberforce, } \\
\text { decision making around the zone }\end{array}$ \\
$\begin{array}{l}\text { Harper-Avoca, Lake Coleridge, Waianiwaniwa, Hororata, 2009 } \\
\text { maximum nutrient loadings and } \\
\text { minimum flow regimes for the river }\end{array}$ & $\begin{array}{l}\text { Hawkins rivers and lowlands streams and water that flows } \\
\text { into Te Waihora, and are bounded by the Selwyn District }\end{array}$ \\
& Council Government Boundary
\end{tabular}

Te Waihora Governance Group (TWGG)

Provide for an enduring, collaborative Relationships between Te Rūnanga o Ngāi Tahu, relationship between the Parties, for Environment Canterbury and Selwyn District Council to the collaborative sharing of functions, work in partnership to implement their responsibilities duties, and powers to commit to (statutory and cultural) within the Catchment including enhance the practice of sustainable the lake. Excludes the Joint Management Plan management within the catchment arrangement under the Ngāi Tahu Claims Settlement Act 1998 (Government of New Zealand 1998).

TANK

To enable present and future Tutaekuri, Ahuriri, Ngaruroro and Karamu rivers and the generations to gain the greatest social, Heretaunga Plain Aquifer System, including making economic, recreational, and cultural recommendations on the flow regime, water allocation, benefits from our water resources surface and ground water quality, involvement of Tangata within an environmentally sustainable Whenua in decision making, Mātauranga Māori in framework

monitoring and reporting, security of water supply for water users, and policies affecting freshwater management

Collaborative decision making for the freshwater resources in the greater Heretaunga and Ahuriri region (2014)
Te Waihora Co-Governance Agreement 2014 
Ecology and Society 22(4): 28

https://www.ecologyandsociety.org/vol22/iss4/art28/

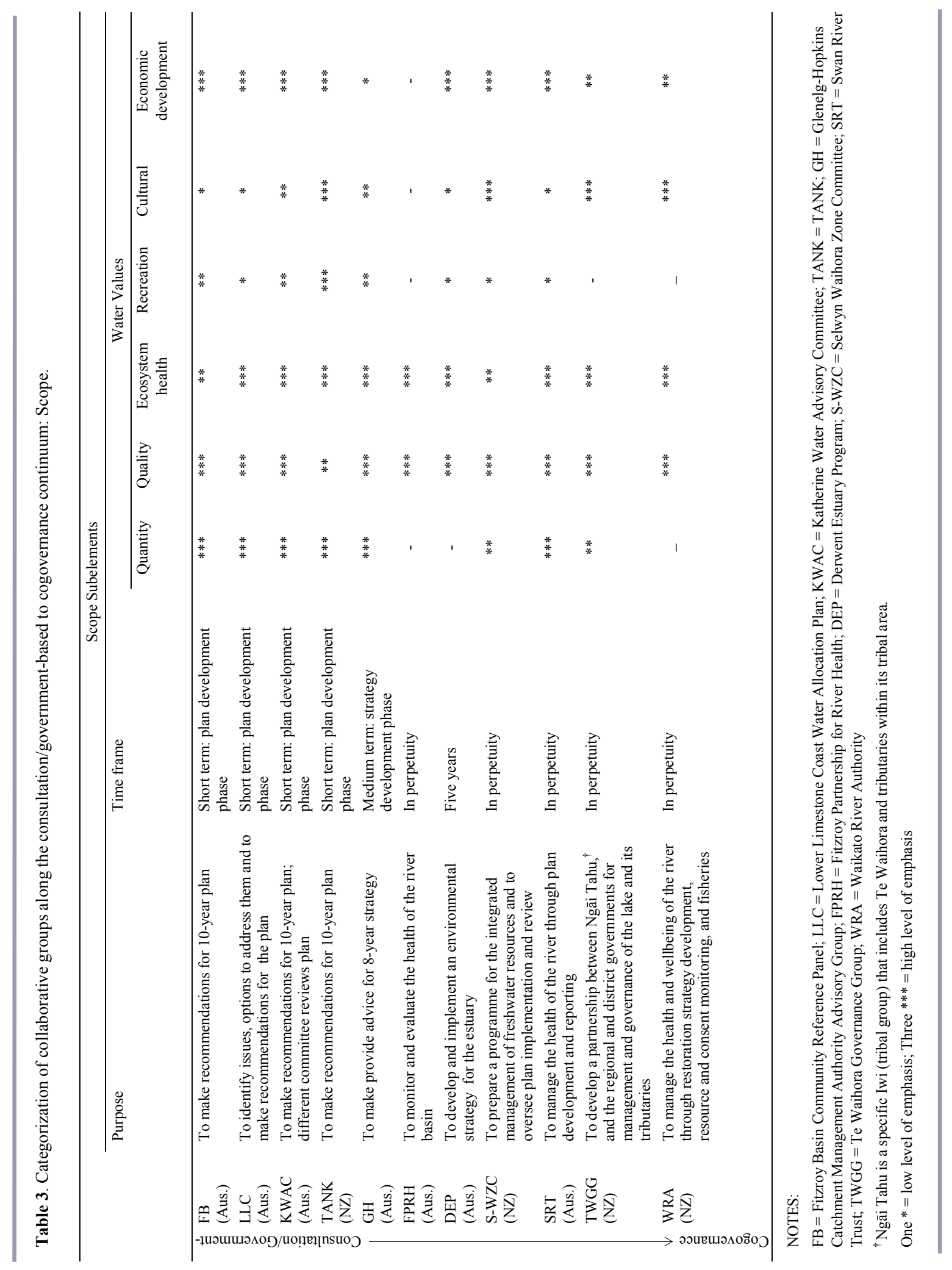


Table 4. Categorization of collaborative groups along the consultation/government-based to cogovernance continuum: Governance subelements (1-4).

\begin{tabular}{|c|c|c|c|c|c|}
\hline & & \multicolumn{4}{|c|}{ Governance Subelements (1-4) } \\
\hline & & Group membership & Establishment of subgroups & $\begin{array}{l}\text { Indigenous } \\
\text { representation }\end{array}$ & $\begin{array}{l}\text { Statutory/ } \\
\text { nonstatutory }\end{array}$ \\
\hline \multirow{10}{*}{ 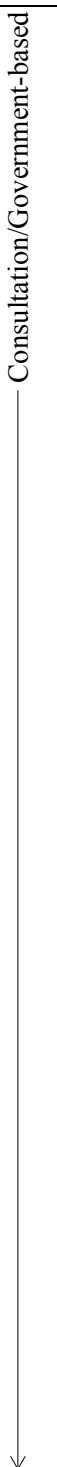 } & $\begin{array}{l}\text { FB } \\
\text { (Aus.) }\end{array}$ & State government appointed. & Not specified & Not specified & Statutory \\
\hline & $\begin{array}{l}\text { LLC } \\
\text { (Aus.) }\end{array}$ & $\begin{array}{l}\mathrm{NRM}^{\dagger} \text { Board responsible for plan } \\
\text { preparation. Appoints water allocation } \\
\text { plan Reference Group. }\end{array}$ & $\begin{array}{l}\text { Reference Group comprises } \\
\text { representatives from forestry, } \\
\text { and agricultural industries and } \\
\text { the } \mathrm{SA}^{\dagger} \text { Farmers' Federation } \\
\text { and the Conservation Council } \\
\text { of South Australia. }\end{array}$ & $\begin{array}{l}\text { One member of the } \\
\text { NRM Board must } \\
\text { represent the } \\
\text { interests of } \\
\text { Aboriginal people. }\end{array}$ & Statutory \\
\hline & $\begin{array}{l}\text { KWAC } \\
\text { (Aus.) }\end{array}$ & $\begin{array}{l}\text { Advisory Committee established } \\
\text { under Territory legislation; } 13 \\
\text { members. }\end{array}$ & $\begin{array}{l}\text { Technical Expert Group. Other } \\
\text { technical advisors as required. }\end{array}$ & $\begin{array}{l}\text { Committee includes } \\
\text { two indigenous } \\
\text { representatives. }\end{array}$ & Statutory \\
\hline & $\begin{array}{l}\text { TANK } \\
(\mathrm{NZ})\end{array}$ & $\begin{array}{l}\text { Committee appointed by Hawkes Bay } \\
\text { Regional Council. } 30 \text { representatives; } \\
\text { broad based. }\end{array}$ & Not specified & $\begin{array}{l}\text { Ten indigenous } \\
\text { representatives } \\
\text { decided by the } \\
\text { Tangata Whenua. }\end{array}$ & Statutory \\
\hline & $\begin{array}{l}\text { GH } \\
\text { (Aus.) }\end{array}$ & $\begin{array}{l}\mathrm{CMA}^{\dagger} \text { responsible for strategy } \\
\text { preparation. Appoints advisory group } \\
\text { with community (5) and agency or } \\
\text { industry representatives }(5) \text {, plus } \\
\text { indigenous community nominee (1). }\end{array}$ & Not specified & $\begin{array}{l}\text { One indigenous } \\
\text { community nominee } \\
\text { on advisory group. }\end{array}$ & Statutory \\
\hline & $\begin{array}{l}\text { FPRH } \\
\text { (Aus.) }\end{array}$ & $\begin{array}{l}\text { Voluntary membership (includes } \\
\text { industry, universities, state, and local } \\
\text { governments). Partnership hosted by } \\
\text { nonstatutory NRM group. }\end{array}$ & $\begin{array}{l}\text { Management committee } \\
\text { (nominees from partners); } \\
\text { science advisory panel; } \\
\text { technical network. }\end{array}$ & $\begin{array}{l}\text { None, but } \\
\text { partnership open to } \\
\text { all interested } \\
\text { parties. }\end{array}$ & $\begin{array}{l}\text { Nonstatutory } \\
\text { MOU }^{\dagger}\end{array}$ \\
\hline & $\begin{array}{l}\text { DEP } \\
\text { (Aus.) }\end{array}$ & $\begin{array}{l}\text { State and local governments, industry, } \\
\text { universities. }\end{array}$ & $\begin{array}{l}\text { Steering Committee; Technical } \\
\text { Working Group; advisory } \\
\text { issues-based groups as required. }\end{array}$ & None & $\begin{array}{l}\text { Nonstatutory } \\
\text { MOU }^{\dagger}\end{array}$ \\
\hline & $\begin{array}{l}\text { S-WZC } \\
(\mathrm{NZ})\end{array}$ & $\begin{array}{l}\text { Committee includes representatives } \\
\text { from Tangata Whenua }(5), \text { Te } \\
\text { Rūnanga o Ngāi Tahu }{ }^{\ddagger}(1) \text {, district } \\
\text { council (1), regional council (1), } \\
\text { community (6). }\end{array}$ & $\begin{array}{l}\text { Subsidiary nonspecified focus } \\
\text { groups that inform the } \\
\text { committee. }\end{array}$ & $\begin{array}{l}\text { Yes, as members of } \\
\text { the committee }\end{array}$ & $\begin{array}{l}\text { Statutory } \\
\text { terms of } \\
\text { reference }\end{array}$ \\
\hline & $\begin{array}{l}\text { SRT } \\
\text { (Aus.) }\end{array}$ & $\begin{array}{l}\text { Board comprises state government } \\
\text { appointees (6), one appointed by } \\
\text { minister (but nominated by WA LGA } \\
\text { Association), and CEO of appropriate } \\
\text { state government department. }\end{array}$ & $\begin{array}{l}\text { River Protection Advisory } \\
\text { Committee includes relevant } \\
\text { agency representatives. Other } \\
\text { subgroups formed as required. }\end{array}$ & $\begin{array}{l}\text { No indigenous } \\
\text { representatives on } \\
\text { Board }\end{array}$ & Statutory trust \\
\hline & $\begin{array}{l}\text { TWGG } \\
(\mathrm{NZ})\end{array}$ & $\begin{array}{l}\text { Governance group includes } \\
\text { representatives from regional } \\
\text { government (4), district government } \\
\text { (1) and Tangata Whenua }{ }^{+}(5) \text {. }\end{array}$ & 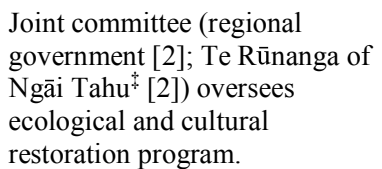 & $\begin{array}{l}50 \% \text { Indigenous } \\
\text { representation }\end{array}$ & $\begin{array}{l}\text { Nonstatutory } \\
\text { MOU }^{\dagger}\end{array}$ \\
\hline 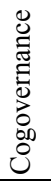 & $\begin{array}{l}\text { WRA } \\
(\mathrm{NZ})\end{array}$ & $\begin{array}{l}\text { Authority includes representatives } \\
\text { from Iwi }{ }^{\ddagger}(5) \text {, regional council } \\
\text { nominees (2), and three others } \\
\text { (nominated on advice from national } \\
\text { government). }\end{array}$ & $\begin{array}{l}\text { Includes Waikato River Clean- } \\
\text { up Trust, which manages a } \\
\text { competitive restoration fund. }\end{array}$ & $\begin{array}{l}50 \% \text { Indigenous } \\
\text { representation }\end{array}$ & Statutory \\
\hline
\end{tabular}

\section{NOTES:}

FB = Fitzroy Basin Community Reference Panel; LLC = Lower Limestone Coast Water Allocation Plan; KWAC = Katherine Water Advisory Committee; TANK = TANK; GH = Glenelg-Hopkins Catchment Management Authority Advisory Group; FPRH

= Fitzroy Partnership for River Health; DEP = Derwent Estuary Program; S-WZC = Selwyn Waihora Zone Committee; SRT = Swan River Trust; TWGG = Te Waihora Governance Group; WRA = Waikato River Authority

${ }^{\dagger} \mathrm{CMA}=$ catchment management authority, $\mathrm{LGA}=$ local government area, $\mathrm{MOU}=$ memorandum of understanding, $\mathrm{NRM}=$ natural resource management, $\mathrm{SA}=$ South Australia, WA $=$ Western Australia

* The term 'tangata whenua' refers to Māori people from a particular area/place; Iwi refers to tribal group; and Ngāi Tahu is a specific Iwi that includes Te Waihora and tributaries within its tribal area. 
Table 5. Categorization of collaborative groups along the consultation/government-based to cogovernance continuum: Governance subelements (5-8).

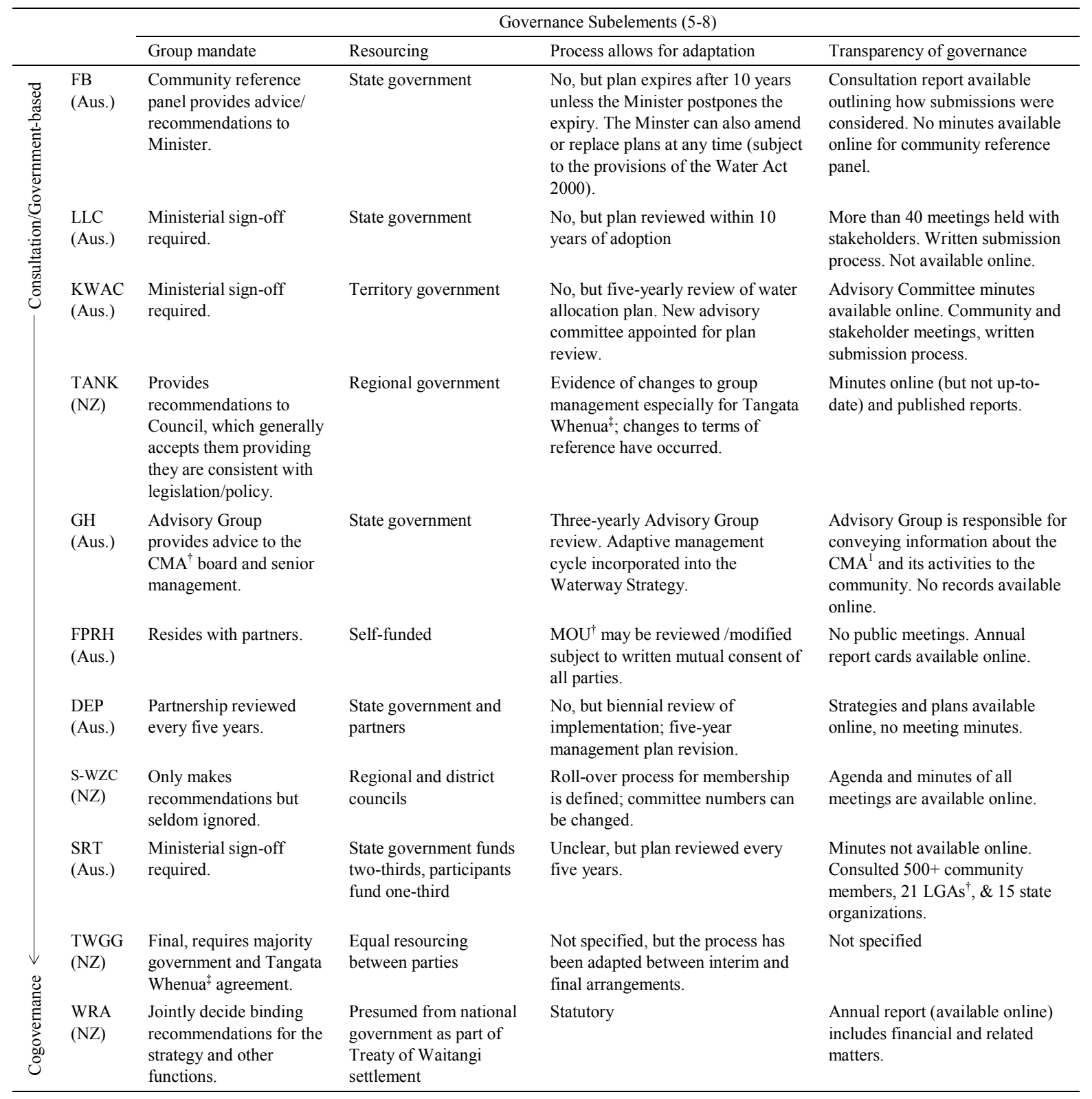

\section{NOTES:}

FB = Fitzroy Basin Community Reference Panel; LLC = Lower Limestone Coast Water Allocation Plan; KWAC = Katherine Water Advisory Committee; TANK = TANK; GH = Glenelg-Hopkins Catchment Management Authority Advisory Group; FPRH = Fitzroy Partnership for River Health; DEP = Derwent Estuary Program; S-WZC = Selwyn Waihora Zone Committee; SRT = Swan River Trust; TWGG = Te Waihora Governance Group; WRA = Waikato River Authority

${ }^{\dagger} \mathrm{CMA}=$ catchment management authority, $\mathrm{LGA}=$ local government area, $\mathrm{MOU}=$ memorandum of understanding, $\mathrm{NRM}=$ natural resource management, $\mathrm{SA}=$ South Australia, $\mathrm{WA}=$ Western Australia

‡ The term 'tangata whenua' refers to Māori people from a particular area/place; Iwi refers to tribal group; and Ngāi Tahu is a specific Iwi that includes Te Waihora and tributaries within its tribal area. 
more holistic role. For example, Swan River Trust's (SRT) role includes management plan development, implementation, and review oversight, WRA's includes administration of a competitive natural resource management fund, e.g., $\$ 6 \mathrm{~m}$ in the 2015 round (Waikato River Authority 2015), and the capacity to manage river fisheries (commercial and customary) that fall under the Fisheries Act 1996 (Government of New Zealand 1996).

In all of the cases, governance group arrangements are normally specified through either memorandum of understanding or terms of reference, through the formation of a specific trust or equivalent, or sometimes specified through law, e.g. settlements such as WRA; we refer to these collectively as "agreements." However, the type of agreement does not appear to vary in relation to the extent of power sharing. Group sizes vary from seven to an unlimited size, with no apparent variation along the continuum. In one Australian case (FPRH), membership occurs in three classes based upon level of resourcing provided to the partnership (Fitzroy Partnership for River Health 2013). Cases falling toward the cogovernance end of the continuum were more likely to have a nongovernment appointment process, for example, through indigenous groups determining their own appointments (WRA), through cash contribution (e.g., FPRH), or through elective processes (e.g., DEP), but not in all cases; in the SRT, an example of a community-based collaboration, appointments are still made by government.

Subgroups typically exist in arrangements located toward the cogovernance end of the continuum, which provide for delegation of particular governance functions. In some cases the specific nature of these is outlined in agreements, while in other cases the capacity to do so is merely mentioned. In general, these groups report to the main collaborative group rather than having authority in their own right. In the case of $\mathrm{Te}$ Waihora Governance Group (TWGG), an example of cogovernance, an additional "joint officials group" exists to support the implementation of a range of functional decisions made by the group; thus the arrangement is unique in specifying and overseeing a series of collaborative practices which, through their nature, should support partnered management.

In some cases, once again particularly toward the cogovernance end of the continuum, decision-making methods are specified; in other cases they are not. For example, the WRA agreement identifies that members must reach decisions pursuing consensus decision making (Government of New Zealand 2010; Schedule 6.9); although it provides detailed conflict management mechanisms, it fails to specify exactly what "consensus" decision making involves. In contrast, the TWGG arrangement defines consensus decision making as a majority of each of the party types: indigenous and government (combined local and regional).

Funding for arrangements also shifts from government toward greater partner cofinancing (or derived from settlement) as they move toward cogovernance. All nonstatutory arrangements provide for adaptation of governance arrangements, usually on a five year time frame; this has already occurred in the TWGG and DEP. In some cases, particularly in New Zealand, the workings of these groups are transparent to outside parties, e.g., minutes are publically available, but in other cases they do not appear to be so or at least are not easily accessible.
Indigenous engagement in groups, as opposed to a scope that includes indigenous interests, varies significantly. For Australian cases, Glenelg-Hopkins Catchment Management Authority Advisory Group (GH) and Fitzroy Basin Community Reference Panel (FB) are the only groups with Aboriginal membership, although nothing precludes Aboriginal peoples' membership in other groups. The inclusion of Tangata Whenua (indigenous peoples from a particular area) in all New Zealand arrangements described here can be viewed as an assertion of values and responsibilities upheld through recognition of the Treaty of Waitangi (for additional detail see Jacobson et al. 2014 and the discussion).

New Zealand arrangements toward the cogovernance end of the continuum are based on government-indigenous partnerships. In the case of TWGG, this represents a layering of arrangements building from a joint-management arrangement of the riparian lake margin as specified in treaty settlements, toward engagement in the Zone Implementations Programme, which effectively attempts to manage the quality of water entering the lake, and further through the nonstatutory cogovernance arrangement and associated Whakaora Te Waihora Cultural and Ecological Restoration Program (covering core tributaries and the lake), which together recognizes the interests of Tangata Whenua as a government partner, and enables them to fulfil cultural responsibilities and provides for cultural values, e.g., food resources. A similar scope is provided for through the WRA.

\section{Management}

The main pattern observable along the continuum is inherently due to the broadening responsibilities beyond management plan development to include monitoring and reporting (Table 6). Arguably though, planning inherently involves a degree of evaluation. Country differences were more apparent. All Australian groups have specific monitoring and reporting responsibilities, either through self-assigned responsibilities (FPRH and DEP), or as required by state or other external parties, e.g., Lower Limestone Coast Water Allocation Plan Reference Group (LLC). These responsibilities are generally around outcome monitoring and reporting. Typical reporting is annual but for some it is quarterly (DEP), and others biennial (SRT). Both DEP and FPRH utilize healthy waterways report cards. A report card system is being implemented for the WRA (John Quinn, National Institute of Water and Atmospheric Research, Hamilton, 4 September 2015, personal communication), and another has been implemented for Te Waihora Lake Ellesmere and was reported at the biennial living lake symposia (Lomax et al. 2015). In New Zealand, monitoring is typically less prescriptive, with no specified requirements for Selwyn Waihora Zone Committee (SWZC), TWGG, or TANK. The WRA reports annually. Collaborative arrangement monitoring (see Izurieta et al. 2011) is only explicit for the SRT.

\section{DISCUSSION}

We discuss insights from this assessment through reflecting on the following: (1) Lessons for management of waterways in Australia and New Zealand; (2) Framework application; and (3) Relevance to international audiences.

Lessons for Australia and New Zealand

Although our assessment focused on collaboration, this can be further disaggregated into decision making (i.e., governing), 
Table 6. Categorization of collaborative groups along the consultation/government-based to cogovernance continuum: Management.

\begin{tabular}{|c|c|c|c|}
\hline \multirow{6}{*}{ 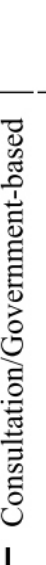 } & & \multicolumn{2}{|c|}{ Management Subelements } \\
\hline & & Monitoring & Reporting \\
\hline & $\begin{array}{l}\text { FB } \\
\text { (Aus.) }\end{array}$ & $\begin{array}{l}\text { Monitoring of outcomes included in plan, but no } \\
\text { monitoring of process. Group is not involved in } \\
\text { monitoring. }\end{array}$ & No role. \\
\hline & $\begin{array}{l}\text { LLC } \\
\text { (Aus.) }\end{array}$ & $\begin{array}{l}\text { Monitoring (required under legislation) of ecological/ } \\
\text { hydrogeological performance, evaluation of } \\
\text { effectiveness/efficiency of environmental water } \\
\text { provisions. }\end{array}$ & $\begin{array}{l}\text { Annual water use reports submitted to the South } \\
\text { Australian Government Department of Environment, } \\
\text { Water and Natural Resources. }\end{array}$ \\
\hline & $\begin{array}{l}\text { KWAC } \\
\text { (Aus.) }\end{array}$ & $\begin{array}{l}\text { Monitoring program based upon performance indicators } \\
\text { of river health, use, quality, cultural purposes, water } \\
\text { trading activity. }\end{array}$ & $\begin{array}{l}\text { River health monitoring reported annually. All other } \\
\text { performance indicators reported once, either prior to five } \\
\text { year review or between five and ten year reviews. }\end{array}$ \\
\hline & $\begin{array}{l}\text { TANK } \\
(\mathrm{NZ})\end{array}$ & No role. & No role. \\
\hline & $\begin{array}{l}\mathrm{GH} \\
\text { (Aus.) }\end{array}$ & $\begin{array}{l}\text { Strategy includes a monitoring, evaluation and reporting } \\
\text { framework consistent with state wide processes on long- } \\
\text { term resource condition, management outcomes, } \\
\text { management outputs. }\end{array}$ & $\begin{array}{l}\text { Annual reporting on activities and outputs, monitoring, } \\
\text { evaluation, and reporting plan reviewed annually, eight- } \\
\text { yearly report on resource condition, end of strategy } \\
\text { review includes reporting on outcome targets. }\end{array}$ \\
\hline & $\begin{array}{l}\text { FPRH } \\
\text { (Aus.) }\end{array}$ & $\begin{array}{l}\text { Integrated waterway health monitoring program at the } \\
\text { catchment scale. }\end{array}$ & Monitoring of programs. \\
\hline & $\begin{array}{l}\text { DEP } \\
\text { (Aus.) }\end{array}$ & $\begin{array}{l}\text { Annual report cards, agricultural water use summaries, } \\
\text { and drinking water summaries are created. }\end{array}$ & $\begin{array}{l}\text { Quarterly e-bulletins, annual report cards, five-yearly } \\
\text { State of the Derwent Estuary report. }\end{array}$ \\
\hline & $\begin{array}{l}\text { S-WZC } \\
(\mathrm{NZ})\end{array}$ & Provides advice on and overview of monitoring. & Provides advice on and overview of reporting. \\
\hline$\ddot{\Xi}$ & $\begin{array}{l}\text { SRT } \\
\text { (Aus.) }\end{array}$ & $\begin{array}{l}\text { Monitoring of collaborative management, social } \\
\text { wellbeing, and river/ecosystem health. }\end{array}$ & $\begin{array}{l}\text { Reports biennially to the Western Australian Minister } \\
\text { for Environment against targets; annual reports are a } \\
\text { statutory requirement. }\end{array}$ \\
\hline$\sum_{0}^{\frac{\pi}{0}}$ & $\begin{array}{l}\text { TWGG } \\
(\mathrm{NZ})\end{array}$ & $\begin{array}{l}\text { Not applicable, as no management functions, although } \\
\text { Whakaora Te Waihora plan does include monitoring. }\end{array}$ & Supposedly annual. \\
\hline ن & $\begin{array}{l}\text { WRA } \\
(\mathrm{NZ})\end{array}$ & $\begin{array}{l}\text { Management plan monitoring, cash grant outcome } \\
\text { monitoring. }\end{array}$ & A publically available and comprehensive annual report. \\
\hline
\end{tabular}

NOTES:

FB = Fitzroy Basin Community Reference Panel; LLC = Lower Limestone Coast Water Allocation Plan; KWAC $=$ Katherine Water Advisory Committee; TANK = TANK; GH = Glenelg-Hopkins Catchment Management Authority Advisory Group; FPRH = Fitzroy Partnership for River Health; DEP = Derwent Estuary Program; S-WZC = Selwyn Waihora Zone Committee; SRT = Swan River Trust; TWGG $=$ Te Waihora Governance Group; WRA = Waikato River Authority

${ }^{\dagger} \mathrm{Ngāi}$ Tahu is a specific Iwi (tribal group) that includes Te Waihora and tributaries within its tribal area;

implementation, and regulation (i.e., management). Our framework assessed collaboration with regard to both of these. Nkhata and Breen (2010) distinguish between governance and management cycles, positing that a governance learning cycle involves articulation and sharing of values, the development of policies and agreements, the enactment of those policies and agreements, and their monitoring and evaluation. The management learning cycle involves objective setting and planning, action taking, and monitoring and evaluation. Coupling of the two depends on effective information flows, addressing and resolving (if possible) competing interests, and lesson sharing. Collaborative management arrangements have an inherent role to play in linking the two learning cycles. Thus, although arrangements of limited scope might serve governance learning purposes, they are unlikely to support effective management learning, particularly where monitoring and evaluation of process and/or outcome are missing. In examples where a succession of arrangements has occurred and/or polycentric arrangements exist, e.g. Te Waihora and Fitzroy Basin, there is a need for ongoing and collaborative monitoring and evaluation of outcomes and processes to ensure activities link and align.

Our analysis identifies lessons for water managers in both countries but with potential application also elsewhere. New Zealand policy makers could strengthen their collaborative 
approaches by including more emphasis on monitoring and evaluation of the group's progress and management outcomes, despite the fact that the WRA is very strong on this element. Such requirements appear absent from the three other New Zealand cases examined. Equally, Australia could think more about broadening the mandate/scope of collaborative approaches so that a more integrated approach to water resource management, including land use, is undertaken. Another opportunity that could be taken in Australia is to more fully embed the collaborative processes to include plan implementation, monitoring, and reporting. Finally, more consideration could be given to taking a more inclusive approach to group membership where appropriate, i.e., by including more community representatives, such as from environmental and recreational interests. These responses highlight jurisdictional biases evident in the practice of collaborative freshwater management, in terms of the actual things people collaborate on, and the capacity of collaborators to learn from the outcomes of their decisions.

Perceptions of water scarcity are arguably a key economic driver of the development of these collaborative processes, in both countries. Ongoing drought in Australia has hastened reforms targeted at greater coordination of water management regimes across jurisdictions. State, federal, and intergovernmental reforms were hastened by the Millennium Drought that was experienced throughout much of Australia from the mid-1990s to approximately 2010 and likely played a greater role in hastening government-led water reform (Smith 2015) resulting in a high number of top-down water planning processes, e.g., Katherine Water Advisory Committee (KWAC) and FB. Droughts along the eastern side of the South Island and in the Hawkes Bay (TANK) of New Zealand have been one of several drivers leading regional government to invest in and promote collaborative approaches through regional strategies, e.g., the Canterbury Water Management Strategy within which the SWZC sits.

In parts of both countries, e.g., the Waikato River (Waikato Regional Council) and Tasmania (DEP), water quality and other environmental drivers are more important. For example, the impacts of Tasmania's forest legacy (Jacobson et al. 2014), and ongoing concerns about nutrient loading affecting water quality in Lake Taupo and the Waikato River system (WRA), and in the Canterbury Plains (TWGG) tend to override water quantity concerns. To some extent, these drivers have been complemented by national fora such as the New Zealand government initiated Land and Water Forum (a multistakeholder initiative advising government on policy initiatives) and the National Policy Statement for Freshwater Management (Ministry for the Environment 2014). Australia's regional approach to natural resource management, also implemented through intergovernmental agreement (Head and Ryan 2004, Curtis et al. 2014), renders regional organizations an appropriate scale for water management (e.g. GH, LLC, KWAC, SRT).

Social drivers also significantly impact collaborative management. Australia has a long tradition of community engagement in community based natural resource management, most likely because of a lack of regional government, which led to the statutory formation and substantive business development of previously catchment based "care" groups (Curtis et al. 2014). It is unsurprising that community engagement exists in cases like SRT and DEP where there has been strong historic engagement, but where funding has waxed and waned. Indigenous cultural considerations are a key driver of the clustering of New Zealand cases toward the cogovernance end of the continuum.

New Zealand's National Policy Statement for Freshwater Management (Ministry for the Environment 2014) directs councils to "involve iwi [tribes] and hāpu [subtribes] in the management of fresh water and freshwater ecosystems in the region" (Ministry for the Environment 2014:18). Water is a tāonga (treasure) for Māori in New Zealand and the mauri (life force) of water is an important driver of ongoing Māori grievance. Tangata Whenua commonly identify issues around freshwater management including the mixing of waterways (both water courses and the release of human waste into streams, rivers, and lakes), the health of food resources, and the mauri of water (Memon and Kirk 2012). For example, the Waikato-Tainui Iwi Management Plan "Whakatupuranga 2050" (a nonstatutory planning document) identifies that "waterways are living embodiments of our tribal identity" (Te Kauhanganui o Waikato Incorporated 2013:4) and likewise the Maahanui Iwi Management Plan (Jolly and Ngā Papatipu Rūnanga Working Group 2013:75) covering TWGG and SWZC areas identifies that "water is a significant cultural resource that connects Ngāi Tahu to the landscape and the culture and traditions of the Tūpuna [ancestors]," noting that current water governance and management has failed, and that a change is needed in the way in which water is valued. Because Treaty of Waitangi claims are progressively being negotiated, there is an increasing range of outcomes with implications for specific catchments. The WRA is a specific outcome of three such settlements and reflects then an ongoing commitment to cogovernance by the national government and Iwi, in a similar way to which the TWGG sets up a process for such arrangements for Tangata Whenua from Ngāi Tahu. This driver helps explain the development in New Zealand of specific and strong collaborative arrangements at the cogovernance end of the continuum.

Unlike Māori in New Zealand, it is difficult to make generalizations about the importance of water to Australian Aboriginal peoples given the cultural diversity that exists. A second issue is the limited extent (geographical and temporal) of formally recognized native title, and even when native title exists, Durette (2008) argues that the legislative provisions are difficult to uphold given the lack of common law recognition for spiritual relationships with country (including water). Although there is low Aboriginal engagement in collaborative groups we reviewed, provisions do exist within the National Water Initiative for indigenous and cultural values for water, under the auspices of environment and other public benefits.

Water plans and planning can (1) incorporate indigenous social, spiritual, and customary aims and strategies for achieving them; (2) take account of the possible existence of native title rights to water in the catchment or aquifer area; (3) potentially allocate water to native title holders (albeit this right appears secondary to commercial values); and (4) account for any water allocated to native title holders for "traditional cultural purposes" (Jackson 2007:63). These processes have however been criticized as struggling to adequately account for Aboriginal interests and rights (Ayre and Mackenzie 2013). Along with multiple examples detailed by Jackson (2007), other instances include Guditj Miring (whose native title and land rights have been settled) who are 
engaged in three other cooperative development, management, and planning processes operating at the landscape scale in the $\mathrm{GH}$ catchment area (see Appendix 1); in South Australia (but not specifically the LLC) significant recent work has been done exploring cultural values associated with water (Nursey-Bray and the Arabana Aboriginal Corporation 2015), and in the land area above the Tindall Limestone Aquifer (KWAC), the Jaowyn people are actively engaged in management of natural resources including National Parks (Nitmuluk) for spiritual and cultural purposes. Thus, water may be a tacit part of other engagement opportunities that exist for traditional owners to express their rights and responsibilities for its management. However, the commitment to do so is weaker than in New Zealand, where treaty settlement, formal agreements outside of treaty settlement, and the Resource Management Act 1991 (Government of New Zealand 1991) provisions provide significantly stronger opportunities, including for fully devolved management (see Jacobson et al. 2016a).

Despite legal recognition of indigenous rights, e.g., through the UN Declaration on the Rights of Indigenous Peoples, both countries have been slow to operationalize recognition, as have Canada and the USA (see for example Lightfoot 2008). Perhaps unsurprisingly then, the comparative analysis reported here indicates variable inclusion of indigenous interests. It is clear that with the increasing emphasis on cogovernance and management opportunities, will come an expectation of achieving high levels of emphasis for recognition of cultural values and associated explicit inclusion of indigenous representation in governance. Such a pattern has emerged in New Zealand but not so clearly in Australia.

\section{Framework application}

The framework was constructed as a way of classifying a selection of existing collaborative approaches to water resource management across Australia and New Zealand. Eleven groups (seven in Australia) were examined and were fitted to the continuum from government (consultation/government-based) to devolved power sharing (cogovernance). Five of the groups could be described as primarily consultative in nature because they were tasked with advising on or making recommendations about the content of a particular planning document and thus typically had a shorter time frame and narrower scope, i.e., groups were at best engaged for shorter periods of time, albeit not for less important activities. The remaining six groups can be considered as arrangements more closely aligned with cogovernance, with three of the four New Zealand groups in these categories. Notable in this grouping is the greater scope, higher level of specified involvement of indigenous peoples, clarity of monitoring and reporting (especially in Australia), and ongoing involvement with more than just planning. Our cogovernance category is novel in terms of the power sharing continuum derived from Sen and Nielsen (1996) and Borrini-Feyerabend et al. (2004), in that it does not necessarily imply direct involvement in actual management implementation, but operates at a relationship and strategic direction setting level, with government and tribal organizations responsible for management implementation.

Our framework extended Borrini-Feyerabend et al. (2004), given that comanagement varies in relation to other factors as well, such as participation scope, formality, and focus on governance and or management. Our framework differs from Hill et al. (2012), because some of the arrangements do not include intercultural purpose, and because we do not consider scope, governance, and management variations as continua. That being said, our indigenous-government partnerships would also not easily align with their typology. First, the Waikato River Authority is specifically a partnership with different components that arguably have different intercultural purposes, such as fisheries management under the Fisheries Act 1996 (Government of New Zealand 1996) as opposed to recommendation and endorsement of a management plan. The intercultural purpose of TWGG is clear though not easily placed along this continuum; it is a partnership agreement that sets out to share power but not in a way that denigrates the existing legislated responsibilities or interests. It includes a set of collaboration processes in relation to various functions of the members (rather than participation), and it defines a new intercultural purpose of good faith and no surprises, while not excluding further treaty or nontreaty-related arrangements. Our framework elements also differ to Szabo and Smyth's (2003) elements that are more prescriptive about resource ownership and property rights, as well as capacity development within an indigenous-government partnership context.

Many of our framework elements correspond with those in Plummer and Fitzgibbons's (2004) comanagement framework. For example, we have considered resource- and rights-based contextual drivers, in a more distinguished social, political, economic, and environmental context. Our scope, governance, and management elements are also similar to that of preconditions, characteristics, and outcomes. However, our analysis identifies that not all of these are relevant, appropriate, or necessary as a means of developing a freshwater management framework, and would, particularly if component subcategories are included, result in a very prescriptive framework that overdifferentiates between examples and inhibits learning across them.

In comparison to Margerum and Robinson (2015), our analysis reveals arrangements are more nuanced, and recognizes that one arrangement can cover actions, organization and policy levels, and be cooperative and collaborative depending on which level is being considered (particularly for layered arrangements). Existing typologies or frameworks of collaborative management therefore do not fit neatly to the freshwater context revealed here.

This comparison of frameworks is itself interesting, highlighting that framework design depends on the following: (1) the elements perceived to be important to a given context, e.g., to indigenousgovernment collaboration; and (2) the intended use of the framework, e.g., detailed description or comparative analysis. In our case, no clear patterns in management subelements emerge across the continuum. For scope subelements, cogovernance arrangements appear more enduring, but do not necessarily include consideration of a broad range of values associated with freshwater. For governance subelements, decision-making mandate, indigenous engagement, and multisourced resourcing were associated with cogovernance, but not whether the process was statutory, transparent, or able to be adapted. We thus concur with Fischer et al. (2014) that a more nuanced understanding of comanagement that recognizes the historicity and evolving nature of arrangements is necessary. 


\section{Relevance to international audiences}

Our results are also relevant elsewhere. For example, if we were to develop an "ideal type" for cogovernance, core ingredients would include flexible but long-term arrangements, focused on a specific array of values deemed important to partners, with equitable resourcing. These are highlighted in arrangements for the management of Auyuittuq National Park, Canada, but not the binding nature of agreed decisions (see Jacobson et al. 2016b). This ideal type also allows for parallel systems of governance, coming together on issues of common interest; as argued for by Fischer et al. (2014) in studies of comanagement of conservation areas in Ethiopia, care needs to be taken in such cases to avoid management by cooption. Our Te Waihora Governance Group (TWGG) and Waikato River Authority (WRA) arrangements appear to have achieved both of these, through multilayered rather than evolutionary arrangements (TWGG), and clarity provided through statutory negotiation (WRA). These arrangements also address conflict tensions observed in South Africa because of lack of agreement on material benefits from comanagement and settlement of land claims (Thondhlana et al. 2016). Conflict has also been evident in the Haida Gwaii settlement (Canada), where there is tacit agreement to disagree on the nature of power-sharing under comanagement despite a collaborative planning process (Takeda and Røpke 2010). Although we applaud efforts for equity in stakeholder representation in comanagement, we must also remember the importance of social network structure (having the right people, in the right place, at the right time) to comanagement success (Crona and Bodin 2006); this is perhaps why there was no discernible pattern in group membership breadth along our continuum.

Finally, our results build on Eberhard et al. (2017), who examined water policy governance networks in six cases in Australia, France and the United States based on governmentality theory. Their work did not examine values nor the changing nature of Indigenous 'power' in new and emerging arrangements, neither within the context of governance or of management. Our proposed framework sits within the context of effective environmental management and provides a mechanism for policy makers to rapidly consider the substantiative nature and choices of design in collaborative management arrangements. This contribution is testable and able to be adapted to context.

\section{CONCLUSION}

Overall, our research makes several important contributions. Theoretically, it has developed a draft framework that has proved beneficial in identifying commonalities but also important differences both within and between countries. These differences offer important insights to managers and policy makers and, in particular, are linked to (1) strengthening monitoring and reporting in the New Zealand context; and (2) more open and inclusive governance processes and broader scope to identify integrated solutions to water resource management issues, e.g., the exercise of indigenous rights and expectations, in the Australian context. These likely apply to other international jurisdictions, e.g., Canada and the United States, where there are similar jurisdictional arrangements.

Our analysis has indicated that the scope, governance arrangements, and management functions of collaborative water management in Australia and New Zealand are intrinsically linked to national scale drivers. A shift toward greater partnership status of arrangements (more common in New Zealand than Australia) provides a more deliberative process, but not necessarily one that is more democratic or representative of all community interests in equal measure.

Three main areas for future research can be identified. A broadening of cases including from other jurisdictions would further test the framework's application. More in-depth, on-theground analysis, would strengthen and potentially modify the cross-cutting elements. Finally, disciplinary-focused evaluation of specific elements would further refine them.

Our framework identifies a provisional continuum from less to more inclusive responses to various drivers of freshwater management. Although we have focused on collaborative arrangements, we are aware that the design principles of Ostrom (1990) could refine the elements within the framework. The significance of our analyses is that we are able to demonstrate a means of comparison that captures the multilevel and polycentric nature of collaborative arrangements evident in Australian and New Zealand freshwater management.

\section{Responses to this article can be read online at: http://www.ecologyandsociety.org/issues/responses. $\mathrm{php} / 9582$}

\section{Acknowledgments:}

This work was funded by the Ministry of Business, Innovation, and Employment (MBIE) in the programme Values, Monitoring and Outcomes (VMO) under contract C09X1003. We thank two anonymous reviewers for their helpful comments.

\section{LITERATURE CITED}

Agrawal, A. 1995. Dismantling the divide between indigenous and scientific knowledge. Development and Change 26:413-439. http://dx.doi.org/10.1111/j.1467-7660.1995.tb00560.x

Armitage, D. R., F. Berkes, and N. Doubleday. 2007. Adaptive comanagement: collaboration, learning, and multi-level governance. UBC Press, Vancouver, British Columbia, Canada.

Ayre, M., and J. Mackenzie. 2013. "Unwritten, unsaid, just known": the role of indigenous knowledge(s) in water planning in Australia. Local Environment 18(7):753-768. http://dx.doi. org/10.1080/13549839.2012.665864

Berkes, F. 2009. Evolution of co-management: role of knowledge generation, bridging organizations and social learning. Journal of Environmental Management 90(5):1692-1702. http://dx.doi. org/10.1016/j.jenvman.2008.12.001

Birnbaum, S. 2016. Environmental co-governance, legitimacy, and the quest for compliance: when and why is stakeholder participation desirable? Journal of Environmental Policy and Planning 18(3):306-323. http://dx.doi.org/10.1080/1523908X.20$\underline{15.1077440}$ 
Borrini-Feyerabend, G. 1996. Collaborative management of protected areas: tailoring the approach to the context. IUCN, Gland, Switzerland.

Borrini-Feyerabend, G., A. Kothari, and G. Oviendo. 2004. Indigenous and local communities and protected areas: towards equity and enhanced conservation. Best practice protected areas guidelines series No. 11. A. Phillips, series editor. IUCN, Gland, Switzerland.

Carlsson, L., and F. Berkes. 2005. Co-management: concepts and methodological implications. Journal of Environmental Management 75:65-76. http://dx.doi.org/10.1016/j.jenvman.2004.11.008

Council of Australian Governments. 1994. Hobart, 25 February 1994 Communiqué. Council of Australian Governments, Canberra, Australia. [online] URL: http://www.environment.gov. au/system/files/resources/6caa5879-8ebc-46ab-8f97-4219b8ffdd98/ files/policyframework.pdf

Crona, B., and Ö. Bodin. 2006. What you know is who you know? Communication patterns among resource users as a prerequisite for co-management. Ecology and Society 11(2):7. http://dx.doi. org/10.5751/ES-01793-110207

Curtis, A., H. Ross, G. R. Marshall, C. Baldwin, J. Cavaye, C. Freeman, A. Carr, and G. J. Syme. 2014. The great experiment with devolved NRM governance: lessons from community engagement in Australia and New Zealand since the 1980s. Australasian Journal of Environmental Management 21 (2):175-199. http://dx.doi.org/10.1080/14486563.2014.935747

Durette, M. 2008. Indigenous legal rights to freshwater: Australia in the international context. CAEPR working paper No. 42/2008. Australian National University, Canberra, Australia.

Eberhard, R., R. Margerum, K. Vella, S. Mayere, and B. Taylor 2017. The practice of water policy governance networks: an international comparative case study analysis. Society \& Natural Resources 30(4):453-470. http://dx.doi.org/10.1080/08941920.20$\underline{16.1272728}$

Fischer, A., D. T. Wakjira, Y. T. Weldesemaet, and Z. T. Ashenafi. 2014. On the interplay of actors in the co-management of natural resources - a dynamic perspective. World Development 64:158-168. http://dx.doi.org/10.1016/j.worlddev.2014.05.026

Fitzroy Partnership for River Health. 2013. Operating rules: v.11. Fitzroy Partnership for River Health, Rockhampton, Queensland, Australia. [online] URL: http://riverhealth.org.au/ wp-content/uploads/2015/02/Riverhealth-Operating-Rules.pdf

Fitzroy Partnership for River Health. [date unknown]. Fitzroy Basin report card 2014-15. Fitzroy Partnership for River Health, Rockhampton, Queensland, Australia. [online] URL: http:// riverhealth.org.au/report_card/pdfreport/2014/FPRH_2014_reportCard. pdf

Government of New Zealand. 1991. Resource Management Act 1991. Government of New Zealand, Wellington, New Zealand. [online] URL: http://www.legislation.govt.nz/act/public/1991/0069/ latest/DLM230265.html

Government of New Zealand. 1996. Fisheries Act 1996. Government of New Zealand, Wellington, New Zealand. [online]
URL: http://www.legislation.govt.nz/act/public/1996/0088/latest/ DLM394192.html

Government of New Zealand. 1998. Ngāi Tahu Claims Settlement Act 1998. Government of New Zealand, Wellington, New Zealand.

Government of New Zealand. 2010. Waikato-Tainui Raupatu Claims (Waikato River) Settlement Act 2010. Government of New Zealand, Wellington, New Zealand. http://www. waikatoriver.org.nz/wp-content/uploads/2011/07/

WaikatoRiverSettlementAct.pdf

Government of New Zealand. 2012. Nga Wai o Maniapoto (Waipa River) Act 2012. Government of New Zealand, Wellington, New Zealand.

Government of Northern Territory. 1992. Water Act 1992. Government of Northern Territory, Darwin, Australia.

Head, B., and N. Ryan. 2004. Can co-governance work? Regional natural resource management in Queensland, Australia. Society and Economy 26(2-3):361-382. http://dx.doi.org/10.1556/

SocEc. 26.2004.2-3.11

Hill, R., C. Grant, M. George, C. J. Robinson, S. Jackson, and N. Abel. 2012. A typology of indigenous engagement in Australian environmental management: implications for knowledge integration and social-ecological system sustainability. Ecology and Society 17(1):23. http://dx.doi.org/10.5751/ES-04587-170123

Hockings, M., S. Stolton, and N. Dudley. 2004. Management effectiveness: assessing management of protected areas? Journal of Environmental Policy and Planning 6(2):157-174. http://dx.doi. org/10.1080/1523908042000320731

Intergovernmental Agreement on a National Water Initiative. 2004. [online] URL: https://www.pc.gov.au/inquiries/current/ water-reform/national-water-initiative-agreement-2004.pdf

Izurieta, A., B. Sithole, N. Stacey, H. Hunter-Xenie, B. Campbell, P. Donohoe, J. Brown, and L. Wilson. 2011. Developing indicators for monitoring and evaluating joint management effectiveness in protected areas in the Northern Territory, Australia. Ecology and Society 16(3):9. http://dx.doi.org/10.5751/ES-04274-160309

Jackson, S. 2007. Indigenous interests and the National Water Initiative: water management, reform and implementation. NAILSMA, Darwin, Australia.

Jacobson, C., M. Manseau, G. Mouland, A. Brown, A. Nakashuk, B. Etooangat, M. Nakashuk, D. Siivola, L.-M. Kaki, J. Kapik, M. Evic, A. Kennianak, and D. Koonelieusee. 2016. Cooperative management of Auyuittuq National Park: moving towards a greater emphasis and recognition of indigenous aspirations for the management of their lands. Pages 3-21 in T. M. Hermann and T. Martin, editors. Indigenous peoples' governance of land and protected territories in the Arctic. Springer, Heidelberg, Germany. http://dx.doi.org/10.1007/978-3-319-25035-9_1

Jacobson, C., K. F. D. Hughey, A. J. J. Lynch, M. Nursey-Bray, M. O’Connell, P. G. Munro, K. Vella, D. Whiley, S. Dovers, and R. W. Carter. 2014. Twenty years of pacifying responses to environmental management. Australasian Journal of Environmental Management 21:143-174. http://dx.doi.org/10.1080/14486563.2014.917594 
Jacobson, C., H. Matunga, H. Ross, and R. W. Carter. 2016. Mainstreaming indigenous perspectives: 25 years of New Zealand's Resource Management Act. Australasian Journal of Environmental Management 23(4):331-337. http://dx.doi. org/10.1080/14486563.2016.1259201

Jentoft, S., and B. McCay. 1995. User participation in fisheries management: lessons drawn from international experiences. Marine Policy 19(3):227-246. http://dx.doi.org/10.1016/0308-597X (94)00010-P

Jolly, D. and Ngā Papatipu Rūnanga Working Group. 2013. Maahanui Iwi management plan. Ngāi Tūāhuriri Rūnanga, Te Hapū o Ngāti Wheke (Rāpaki), Te Rūnanga o Koukourārata, Ōnuku Rūnanga, Wairewa Rūnanga, Te Taumutu Rūnanga, New Zealand. [online] URL: http://www.hurunui.govt.nz/assets/ Documents/Iwi/Mahaanui-Iwi-Management-Plan-2013.pdf

Lightfoot, S. R. 2008. Indigenous rights in international politics: the case of "overcompliant" liberal states. Alternatives 33 (1):83-104. http://dx.doi.org/10.1177/030437540803300105

Lomax, A. J., K. A. Johnston, K. F. D. Hughey, and K. J. W. Taylor. 2015. Te WaihoralLake Ellesmere: state of the lake 2015. Technical Report No. 2, Waihora Ellesmere Trust, Christchurch, New Zealand. [online] URL: http://www.wet.org.nz/wp-content/ uploads/2015/10/2015-State-of-the-Lake-FULL-REPORT.pdf

Margerum, R. D. 2008. A typology of collaboration efforts in environmental management. Environmental Management 41:487-500. http://dx.doi.org/10.1007/s00267-008-9067-9

Margerum, R. D., and C. J. Robinson. 2015. Collaborative partnerships and the challenges for sustainable water management. Current Opinion in Environmental Sustainability 12:53-58. http://dx.doi.org/10.1016/j.cosust.2014.09.003

Memon, P. A., and N. Kirk. 2012. Role of indigenous Māori people in collaborative water governance in Aotearoa/New Zealand. Journal of Environmental Planning and Management 55 (7):941-959. http://dx.doi.org/10.1080/09640568.2011.634577

Ministry for the Environment. 2014. National policy statement for freshwater management. Ministry for the Environment, Wellington, New Zealand. [online] URL: http://www.mfe.govt. nz/publications/fresh-water/national-policy-statement-freshwatermanagement-2014

Nkhata, B. A., and C. Breen. 2010. A framework for exploring integrated learning systems for the governance and management of public protected areas. Environmental Management 45 (2):403-413. http://dx.doi.org/10.1007/s00267-009-9410-9

Nursey-Bray, M., and the Arabana Aboriginal Corporation. 2015. The Arabana people, water and developing cultural indicators for country. Technical Report Series No. 15/29, Goyder Institute for Water Research, Adelaide, Australia.

Ostrom, E. 1990. Governing the commons: the evolution of institutions for collective action. Cambridge University Press, Cambridge UK. http://dx.doi.org/10.1017/CBO9780511807763

Pigram, J. J. J. 2006. Australia's water resources: from use to management. CSIRO Publishing, Collingwood, Australia.
Plummer, R., and J. Fitzgibbon 2004. Co-management of natural resources: a proposed framework. Environmental Management 33 (6):876-885. http://dx.doi.org/10.1007/s00267-003-3038-y

Sen, S., and J. R. Nielsen. 1996. Fisheries co-management: a comparative analysis. Marine Policy 20(5):405-418. http://dx.doi. org/10.1016/0308-597X(96)00028-0

Smith, E. F. 2015. Structuring for serendipity: family Wealth creation, farmer autonomy and the pursuit of security in an uncertain Australian countryside. Dissertation. The University of Sydney, Sydney, Australia. [online] URL: http://ses.library.usyd. edu.au/handle/2123/13363

Smyth, D. 2001. Joint management of national parks. Pages 75-91 in R. Baker, E. Young, and J. Davies, editors. Working on country: indigenous environmental management in Australia. Oxford University Press, Oxford, UK.

State Government of Queensland. 2000. Water Act 2000. State Government of Queensland, Brisbane, Australia. [online] URL: https://www.legislation.qld.gov.au/LEGISLTN/SUPERSED/W/ WaterA00 006 080701.pdf

State Government of South Australia. 2004. Natural Resource Management Act 2004. State Government of South Australia, Adelaide, Australia.

State Government of Victoria. 1989. Water Act 1989. State Government of Victoria, Melbourne, Australia. [online] URL: http://www.austlii.edu.au/au/legis/vic/consol_act/wa198983/

State Government of Western Australia. 2006. Swan and Canning Rivers Management Act 2006. State Government of Western Australia, Perth, Australia.

Szabo, S., and D. Smyth. 2003. Indigenous protected areas in Australia. Pages 145-164 in H. Jaireth and D. Smyth, editors. Innovative governance: indigenous peoples, local communities and protected areas. IUCN, New Delhi, India.

Takeda, L., and I. Røpke. 2010. Power and contestation in collaborative ecosystem-based management: the case of Haida Gwaii. Ecological Economics 70:178-188. http://dx.doi. org/10.1016/j.ecolecon.2010.02.007

Te Kauhanganui o Waikato Incorporated. 2013. Whakatupuranga Waikato-Tainui 2050. Te Kauhanganui o Waikato Incorporated, Ngaruawahia, New Zealand. [online] URL: http://www.tgh.co. nz/wp-content/uploads/WhakatupurangaWT20501.pdf

Thondhlana, G., G. Cundhill, and T. Kepe. 2016. Comanagement, land rights, and conflicts around South Africa's Silaka Nature Reserve. Society \& Natural Resources 29 (4):403-417. http://dx.doi.org/10.1080/08941920.2015.1089609

Waikato River Authority. 2015. Fifth funding round gets underway. (Media release). Waikato River Authority, Hamilton, New Zealand. [online] URL: http://www.waikatoriver.org.nz/mediarelease-fifth-funding-round-gets-underway/ 
Appendix 1. Key sources for each case organized by country.

\section{Australian national documents}

Intergovernmental Agreement on a National Water Initiative. (2004). Retrieved 24 July 2015 from

http://www.nwc.gov.au/ data/assets/pdf file/0008/24749/Intergovernmental-Agreement-on-anational-water-initiative.pdf

National Water Commission. (2013). The national water planning report card 2013. Canberra, Australia: National Water Commission.

\section{Derwent Estuary Program (Tasmania, Australia)}

Coughanowr, C., \& Whitehead, J. (2013). The Derwent Estuary Program: A collaborative model for science-based management, Tasmania, Australia. Ocean and Coastal Management, 86, 110-118.

Derwent Estuary Program. (2015). State of the Derwent Report 2015. Retrieved 4 September 2015 from http://www.derwentestuary.org.au/stateofderwent2015/

Derwent Estuary Program. (2014). A 5 Year Voluntary Partnership between the Government of Tasmania the Brighton, Clarence City, Derwent Valley, Glenorchy City, Hobart City and Kingborough Councils and Hydro Tasmania, Norske Skog Boyer, Nystar Hobart, Tasmanian Ports Corporation and Taswater for the environmental management of the Derwent Estuary. Retrieved 24 July 2015 from http://www.derwent estuary.org.au/assets/DEP Partnership Agreement FINAL 2014.pdf

Derwent Estuary Program. (2009). Derwent Estuary Program Environmental Management Plan. Retrieved 4 September 2015 from http://www.derwentestuary.org.au/assets/Final EMP 2009.pdf

Water Management Act 1999 (Tas.)

Fitzroy Basin Water Resource Plan (Queensland, Australia)

Department of Natural Resources and Mines. (2014). Fitzroy Basin: Draft resource operations plan amendment. Brisbane: State of Queensland.

Department of Natural Resources and Mines. (2014). Fitzroy Basin draft amended water resource plan and resource operations plan: Overview report. Brisbane: State of Queensland.

Water Resource (Fitzroy Basin) Amendment Plan 2014 (Water Act 2000). Consultation draft.

Department of Natural Resources and Mines. (2014). Fitzroy Basin resource operations plan. Brisbane: State of Queensland.

Fitzroy Basin Association. (2013). Our waterways. Retrieved 27 July 2015 from http://www.fba.org.au/ourwaterways/

Fitzroy Basin Association. (2011). Environmental values for the Fitzroy: Community Consultation (updated July 2011). Rockhampton: Fitzroy Basin Association.

Water Resource (Fitzroy Basin) Plan 2011 (Water Act 2000) (Qld.).

Water Act 2000 (Qld.)

Fitzroy Partnership for River Health (Queensland, Australia)

Fitzroy Partnership for River Health. (n.d.) Memorandum of understanding. Retrieved 27 July 2015 from http://riverhealth.org.au/wp-content/uploads/2015/02/Riverhealth-Memorandum-ofUnderstanding.pdf

Fitzroy Partnership for River Health. (n.d.). Fitzroy Basin Report Card 2014-15. Retrieved 14 November 2016 from http://riverhealth.org.au/report card/pdfreport/2014/FPRH 2014 reportCard.pdf

Fitzroy Partnership for River Health. (2013). Operating rules (v.11). Retrieved 27 July 2015 from http://river health.org.au/wp-content/uploads/2015/02/Riverhealth-Operating-Rules.pdf

Water Act 2000 (Q/d.)

Glenelg Hopkins Waterway Strategy (Victoria, Australia)

Department of Sustainability and Environment. (2011). Western region sustainable water strategy. Melbourne, Australia: The State of Victoria, Department of Sustainability and Environment.

Glenelg Hopkins Catchment Management Authority. (2014). Glenelg Hopkins Waterway Strategy 2014-2022. Glenelg Hopkins Catchment Management Authority. Retrieved 4 September 2015 from http://www.ghcma.vic.gov.au/master-nav/publications/plans/glenelg-hopkins-waterway-strategy/

Water Act 1989 (Vic)

Water Act 1989: Statement of Obligations Catchment Management Authority 2006 (Vic.)

Budj Bim Master Plan 2014, Gunditj Mirring Traditional owners Aboriginal Corporation http://www.rdv.vic.gov.au $\angle$ data/assets/pdf file/0006/1165380/Budj-Bim-Master-Plan-Summary-EMAIL-VERSION.PDF

Ngootyoong Mirring, Ngootyoong Mara South West Management Plan, 2011, Parks Victoria http://parkweb.vic.gov.au/ data/assets/pdf file/0003/662763/NGNM-South-West-ManagementPlan.pdf 
Gillet, V., McKay, J., \& Keremane, G. (2014). Moving from local to state water governance to resolve a local conflict between irrigated agriculture and commercial forestry in South Australia. Journal of Hydrology, 519(PC), 2456-2467.

Natural Resources Management Act 2004 (Sth Australia)

South East Natural Resources Management Board. (2013). Water allocation plan for the Lower Limestone Coast Prescribed Wells Area. South Australia: Government of South Australia. Retrieved 4 September 2015 from http://www.naturalresources.sa.gov.au/southeast/water-and-coast/water-allocationplans/lower-limestone-coast

Swan River Trust (Western Australia)

Robins, G., Bates, L., \& Pattison, P. (2011). Network governance and environmental management: Conflict and cooperation. Public Administration, 89(4), 1293-1313.

Swan and Canning Rivers Management Act 2006 (W. Australia)

Swan River Trust. River Protection Strategy for the Swan Canning Riverpark. Perth, Western Australia: Government of Western Australia. Retrieved 4 September 2015 from http://www.swanrivertrust.wa.gov.au/docs/river-management/draft-river-protection-strategy-riverprotection-strategy.pdf

Rights in Water and Irrigation Act 1914 (W. Australia)

Tindall Limestone Aquifer (Katherine) Water Allocation Plan (Northern Territory, Australia)

Department of Land Resource Management. (2015). Katherine Tindall Limestone Aquifer Water Allocation Plan. Retrieved 27 July 2015 from http://Irm.nt.gov.au/water/water allocation/plans/kwap

Tindall limestone Aquifer, Katherine Water Allocation Plan 2009-2019.

Water Act 1992 (Northern Territory)

\section{New Zealand national documents}

Treaty of Waitangi 1840. Retrieved 3 November 2015 from http://www.nzhistory.net.nz/politics/treaty/readthe-treaty/english-text

Resource Management Act 1991. Retrieved 3 November 2015 from http://www.legislation.govt.nz/act/public/ 1991/0069/latest/DLM230265.html

National Policy Statement for Freshwater Management 2014. Retrieved 3 November 2015 from http://www.mfe. govt.nz/sites/default/files/media/Fresh\%20water/nps-freshwater-management-jul-14.pdf

Selwyn-Waihora Zone Committee (South Island, New Zealand)

Canterbury Water Management Strategy 2009. Retrieved 3 November 2015 from http://ecan.govt.nz/publica tions/Plans/cw-canterbury-water-wanagement-strategy-05-11-09.pdf

Zone Implementation Programme 2011. Retrieved 3 November 2015 from http://ecan.govt.nz/publications/ General/cw-selwyn-waihora-zip.pdf

Te Waihora Co-governance Group (South Island, New Zealand)

Ngāi Tahu Claims Settlement Act 1998. Retrieved 3 November 2015 from http://www.legislation.govt.nz/act/ public/1998/0097/latest/DLM429090.html

Te Waihora Co-Governance Agreement 2014. Retrieved 3 November 2015 from http://ecan.govt.nz/ publications/General/te-waihora-co-governance-agreement.PDF

Te Waihora Interim co-governance agreement and terms of reference 2011 (since replaced by Te Waihora CoGovernance Agreement 2014)

Memorandum of Understanding in relation to Whakaora Te Waihora 2011 (Ministry of Environment, Te Rūnaga o Ngāi Tahu and Environment Canterbury. Retrieved 3 November 2015 from http://ecan.govt.nz/ publications/General/te-waihora-memo.pdf

Tipa, G. (2015). Cultural health. In A.J. Lomax, K.A Johnston, K.F.D Hughey, K.J.W Taylor (Eds.). Te Waihora/Lake Ellesmere: State of the Lake 2015 (section 10, pp. 31-32). Christchurch, New Zealand: Environment Canterbury.

Whakaora Te Waihora Joint Cultural and Ecological Restoration Plan 2011, Te Waihora Co-governance Group. Retrieved 3 November 2015 from http://ecan.govt.nz/publications/General/joint-cultural-ecologicalrestoration-plan-09-12-2011.pdf

Tutaekuri, Ahuriri, Ngaruroro and Karamu catchments (TANK) (North Island, New Zealand)

Hawkes Bay Regional Council. (n.d.). TANK Project: Land and water management in the Greater Heretaunga and Ahuriri area. Retrieved 3 November 2015 from http://www.hbrc.govt.nz/Hawkes-Bay/Projects/ Pages/tank.aspx

TANK Group. (2014). Collaborative decision making for freshwater resources in the Greater Heretaunga and Ahuriri Region: TANK Group Report, 1 Interim Agreements. Retrieved 3 November 2015 from 
Page $\mathbf{3}$ of $\mathbf{3}$

http://www.hbrc.govt.nz/HBRC-Documents/HBRC\%20Document\%20Library/20140131

TANKReport1FINAL-compressed.pdf

Waikato River Authority (North Island, New Zealand)

Waikato River Authority. (n.d.). Waikato River Authority. Retreived 3 November 2015 from http://www.waikato river.org.nz/about-the-waikato-river-authority/purpose/

Waikato-Tainui Raupatu Claims (Waikato River) Settlement Act 2010. Retrieved 3 November 2015 from http://www.waikatoriver.org.nz/wp-content/uploads/2011/07/WaikatoRiverSettlementAct.pdf? phpMyAdmin=fb2d981894c82972b5a614e87e61f778

Ngati Tuwharetoa, Raukawa, and Te Arawa River Iwi Waikato River Act 2010. Retrieved 3 November 2015 from http://www.legislation.govt.nz/act/public/2010/0119/latest/DLM2921819.html

Nga Wai o Maniapoto (Waipa River) Act 2012 (and He Mahere Taiao - The Maniapoto Iwi Environmental Management Plan). Retrieved 3 November 2015 from http://www.legislation.govt.nz/act/public/ 2012/0029/latest/DLM3335204.html 